\title{
Pelatihan E-Learning Menggunakan LMS Edmodo Bagi Guru SDN 19 Ampenan Kota Mataram
}

\author{
Supriadin, ${ }^{1}$ Muhamad Ikhsan, ${ }^{2}$ Syahrir $^{3}$ \\ Dosen Universitas Pendidikan Mandalika \\ E-mail: Supriadin.undikma@gmail.com
}

\begin{abstract}
Abstrak: Tujuan kegiatan pengabdian pada masyarakat ini adalah mengenalkan aplikasi $E$ elearning berbasis Learning Manaement System (LMS) Edmodo kepada guru SDN 19 Ampenan Kota Mataram. Keterampilan penggunaan media sosial yang dimiliki oleh guru diharapkan mempermudah proses pembelajaran dengan menggunakan Edmodo. Metode kegiatan yang dilakukan dalam pengabdian kepada masyarakat ini adalah dalam bentuk ceramah, diskusi, dan praktek. Pelatihan akan dilakukan selama 1 hari, pelatihan akan fokus terhadap pengemasan konten pembelajaran, melakukan praktek dan simulasi proses pembelajaran dengan memanfaatkan fiturfitur yang ada pada Edmodo. Modul pelatihan diberikan kepada peserta sebagai alat bantu dalam kegiatan praktek di kelas. Kegiatan pelatihan ini dilaksanakan di SD Negeri 19 Ampenan yang dihadiri 8 orang guru. Proses evaluasi dilakukan dengan pengisian kuisioner di akhir pelatihan. Hasil evaluasi pelaksanaan Kegiatan Pengabdian kepada Masyarakat ini menunjukkan bahwa kegiatan ini dapat meningkatkan pemahaman peserta mengenai penggunaan E-learning menggunakan Edmodo serta bermanfaat untuk menunjang proses belajar mengajar yang dilakukan di sekolah. Berdasarkan hasil observasi selama kegiatan, terlihat bahwa aktivitas peserta sangat baik, ini dapat dilihat dari banyaknya indikator-indikator aktivitas pelatihan yang muncul. Begitu juga dengan hasil angket yang diberikan ke peserta di akhir kegiatan, $90 \%$ peserta puas dengan kegiatan ini. Pelaksanaan pelatihan telah dapat mencapai tujuan yang diharapkan, hal ini dapat dilihat dari tugas-tugas yang diberikan kepada peserta dapat diselesaikan dengan baik. Kepada peserta diharapkan hasil pelatihan dapat digunakan untuk mengembangkan media pembelajaran berbasis E-learning menggunakan LMS Edmodo yang sesuai dengan bidang studi yang diajarkan di kelas masing-masing.
\end{abstract}

\section{Kata kunci : Pelatihan e-Learning Menggunakan LMS Edmodo}

\section{LATAR BELAKANG}

Pemanfaatan internet sebagai sarana pendidikan yang kerap dilakukan adalah melalui media E-Learning. Indonesia merupakan negara dengan jumlah penduduk pengguna internet terbanyak di Asia Tenggara. Akan tetapi, berdasarkan survei yang dilakukan oleh Asosiasi Penyelenggara Jasa Internet Indonesia mengenai profil pengguna internet Indonesia tahun 2014, diperoleh data bahwa penggunaan internet di Indonesia sebagai sarana pendidikan hanya $29,3 \%$.

Hal tersebut terjadi karena lemahnya pengetahuan serta keterampilan penggunaan internet, khususnya E-Learning, sebagai media pendukung pendidikan. Lemahnya pengetahuan serta keterampilan ini terjadi di hampir seluruh wilayah Indonesia termasuk Kota Mataram. Kota Mataram adalah sebuah kota yang ada di Provinsi Nusa Tenggara
Barat. Kota Mataram ini dikelilingi oleh Kabupaten Lombok Barat.

Berdasarkan hasil wawancara dengan Kepala Sekolah SDN 19 Ampenan, Muhammad, S.Pd, disebutkan bahwa SDN 19 Ampenan sampai saat ini belum menerapkan E-Learning dalam proses pembelajaran ke siswa. SDN 19 Ampenan telah memiliki sistem E-Learning berbasis Edmodo namun tidak digunakan akibat kurangnya keterampilan guru dalam menggunakannya. Lemahnya kemampuan TIK dan sulitnya pengoperasian Edmodo juga dikeluhkan para guru.

Berbanding terbalik dengan penggunaan internet sebagai sarana pendidikan, berdasarkan survei yang dilakukan APJII tahun 2014 ditemukan data bahwa 87,4\% penduduk Indonesia menggunakan internet untuk mengakses media sosial dan $43,7 \%$ pengguna internet di Indonesia adalah 
pengguna kalangan pelajar dan guru. Hal ini merupakan indikasi bahwa penggunaan media sosial telah menjadi suatu "budaya" dalam kehidupan pelajar, sehingga merupakan suatu tantangan bagi pendidik untuk menggunakan strategi dengan memanfaatkan kultur tersebut.

Dari hasil wawancara dengan beberapa guru serta siswa di SDN 19 Ampenan, sebagian besar tidak mengetahui adanya media sosial Edmodo sebagai salah satu aplikasi E-Learning yang dapat digunakan dalam mendukung proses

pembelajaran dan berinteraksi dengan guru atau siswa lain layaknya media sosial yang ada. Dari proses wawancara juga diperoleh informasi tidak adanya media yang dapat digunakan sebagai sarana berinteraksi antar guru, antar siwa, atau antar guru dan siswa di Kecamatan Sekarbela atau cakupan yang lebih luas, dalam berbagi pengetahuan, informasi dan atau konten pembelajaran. Dari proses observasi yang dilakukan di SDN 19 Ampenan, sarana yang dimiliki sekolah sangatlah mendukung proses pembelajaran menggunakan E-Learning berbasis media sosial Edmodo ini, seperti Guru dan siswa SD pada umumnya juga sudah terbiasa dalam penggunaan laptop atau komputer dalam kegiatan sehari-hari.

Berdasarkan data dan informasi di atas, dipandang perlu untuk memberikan pelatihan penggunaan E-Learning berbasis media sosial Edmodo ini bagi guru dan siswa di SDN 19 Ampenan.

Dari proses wawancara dan observasi yang dilakukan seluruh guru SDN 19 Ampenan merupakan pengguna aktif media sosial seperti Facebook, sehingga pelatihan penggunaan media sosial Edmodo ini diharapkan dapat berjalan secara efektif dan dapat diterapkan dengan baik di sekolah mengingat cara penggunaan Edmodo yang hamper mirip dengan media sosial Facebook.

\section{METODE PENGABDIAN}

Kegiatan pengabdian masyarakat berupa pelatihan pembuatan e-learning menggunakan LMS Edmodo untuk para Guru SDN 19 Ampenan Kelurahan Jempong Baru Kecamatan Sekarbela Kota Mataram dilaksanakan hari Sabtu dan Minggu tanggal
22 Agustus 2020. Sebanyak 8 Guru SDN 19 Ampenan mengikuti kegiatan ini didampingi oleh Kepala Sekolah SDN 19 Ampenan, Guru Mata Pelajaran dan Wali Kelas masingmasing.

Kegiatan Pengabdian masyarakat berupa Pelatihan E-Learning Guru menggunakan LMS Edmodo bagi Guru SDN 19 Ampenan Kelurahan Jempong Baru Kecamatan Sekarbela Kota Mataram dilaksanakan dengan metode : (a) Seminar (Ceramah dan Diskusi); (b) Workshop penggunaan Learning Management System (LMS) Edmodo; dan (c) Evaluasi Hasil Pelatihan.

\section{HASIL DAN PEMBAHASAN}

Kegiatan Pengabdian kepada Masyarakat ini dengan judul Pelatihan E-Learning menggunakan LMS Edmodo bagi Guru SDN 19 Ampenan Kelurahan Jempong Baru Kecamatan Sekarbela Kota Mataram. Jumlah peserta pada kegiatan ini adalah 8 orang. Pelaksanaan pelatihan dilakukan 1 hari (kali tatap muka) dan 7 hari tugas mandiri. Adapun tugas mandirinya adalah guru-guru diminta membuat media pembelajaran dan mengelola kelas secara virtual dengan menggunakan website elearning Edmodo yaitu http://edmodo.com.

Dalam melaksanakan pengabdian pada masyarakat yang perlu disampaikan, yaitu pengenalan dan pemanfaatan E-Learning sebagai Media Pembelajaran di mana lebih fokus dalam memberikan informasi mengenai pemanfaatan E-Learning, pengenalan Edmodo, proses mendaftar di Edmodo, sampai pada pengenalan fitur-fitur dan keunggulan Edmodo. Adapun tujuan kegiatan ini adalah untuk memberikan pengetahuan dasar tentang e-learning kepada peserta, hal ini disebabkan karena sebagian peserta belum mempunyai pengetahuan yang memadai tentang e-learning atau bagaimana cara membuat e-learning itu sendiri. Dengan penjelasan secara detail ini, diharapkan guru paham akan makna dan manfaat serta langkah-langkah pembuatan elearning itu untuk pembelajaran. Kegiatan selanjutnya, secara tutorial tim mempraktekkan langsung cara membuat elearning menggunakan LMS Edmodo. Kegiatan terakhir tim memberi 
kesempatan kepada peserta untuk bertanya apabila ada peserta ada kesulitan dalam pemuatan elearning tersebut. Adapun langkah-langkah dalam membuat e-learning tersebut dapat akan dijelaskan di bawah ini : Pertama pendaftaran akun Edmodo dengan alamat url http://edmodo.com. Dengan terlebih dahulu bisa memilih login sebagai Teacher, Student ataupun Parent. Selanjutnya kita bisa merubah data diri dan mengelola kelas virtual yang ada di dalam fitur edmodo. Di akhir kegiatan peserta telah berhasil membuat media e-learning sendiri menggunakan LMS Edmodo.

Pelaksanaan kegiatan dilakukan selama 1 kali tatap muka dan satu minggu latihan (tugas mandiri) yaitu membuat media secara menyeluruh dan penguploadan bahan ajar dan media sederhana ke dalam e-learning berbasis Edmodo yang telah dikembangkan sebelumnya. Rata-rata kehadiran observasi (pengamatan) dilakukan tim pelaksana terhadap peserta pelatihan dilakukan sejak awal sampai akhir kegiatan. Dalam kegiatan ini yang menjadi observer adalah tim pelaksana dengan menggunakan lembar observer. Kategori pengamatan yang dicatat memuat aspek-aspek sebagai berikut : Aktivitas Peserta Pelatihan: mendengar atau memperhatikan penjelasan tim pelaksana, membaca modul petunjuk pembuatan media ajar interaktif berbasis elearning Edmodo, bertanya dengan tim pelaksana tentang materi pelatihan, mengerjakan tugas yang diberikan berdiskusi dengan teman dalam mengerjakan tugas yang diberikan dan perilaku yang tidak releven dengan kegiatan pelatihan (percakapan yang tidak relevan, mengerjakan sesuatu yang tidak relevan dan melamun). Data yang diperoleh dari lembar observasi diberi skor 1 untuk komponen yang tampak dan diberi skor 0 untuk komponen yang tidak tampak.

Berdasarkan hasil obeservasi selama kegiatan, terlihat bahwa aktivitas peserta sangat baik, ini dapat dilihat dari banyaknya indikator-indikator aktivitas pelatihan yang muncul. Begitu juga dengan hasil angket yang diberikan ke peserta di akhir kegiatan, $90 \%$ peserta puas dengan kegiatan ini dan hanya $10 \%$ masih belum puas hal ini disebabkan karena salah satu peserta tersebut tidak mengikuti kegiatan pelatihan pada pertemuan kedua, sehingga peserta tersebut tidak begitu paham dalam membuat animasi yang bergerak. Untuk mengatasi masalah ini maka tim memberi saran kepada satu peserta yang belum paham tersebut untuk belajar dengan teman sejawatnya yang sama-sama mengikuti pelatihan ini. Kemudian tim memberi harapan semoga hasil kegiatan ini dapat diaplikasikan untuk pembelajaran di kelas.

\section{SIMPULAN}

LMS Edmodo dapat digunakan sebagai salah satu alternatif pengganti E- Learning yang berbasis media sosial. Pelatihan penggunaan Edmodo penting dilakukan untuk meningkatkan pemahaman guru mengenai penggunaan Edmodo dalam kegiatan belajar mengajar di sekolah.

Berdasarkan proses evaluasi dengan pengisian kuisioner di akhir pelatihan, diperoleh hasil antara lain $100 \%$ responden menyatakan bahwa kegiatan pelatihan Edmodo ini sangat bermanfaat serta dapat meningkatkan pemahaman mengenai bagaimana penggunaan Edmodo dalam mendukung kegiatan belajar mengajar. Akan tetapi, terdapat $14,5 \%$ responden yang menyatakan tidak tahu apakah akan menerapkan atau menggunakan Edmodo dalam proses belajar-mengajarnya.

\section{SARAN}

Berdasarkan pelaksanaan serta hasil evaluasi dari kegiatan Pengabdian kepada Masyarakat ini dapat diberikan beberapa saran untuk pelaksanan kegiatan Pengabdian kepada Masyarakat serupa, antara lain : (1) Perlunya pelatihan Edmodo untuk siswa, sehingga penggunaan Edmodo di sekolah dapat berjalan dengan baik nantinya; (2) Pelatihan penggunaan Edmodo dapat dibarengi dengan pelatihan pembuatan konten digital atau media pembelajaran digital bagi guru; dan (3) Perlunya pembahasan yang mendalam saat penggunaan fitur quiz di Edmodo yang melibatkan formula atau persamaan Matematika. 


\section{DAFTAR PUSTAKA}

Badan Pusat Statistik Kabupaten Pamekasan. 2015. Kecamatan Batumarmar dalam Angka 2015. Katalog BPS.

Basori. 2013. Pemanfaatan Social Learning Network "Edmodo" dalam Membantu Perkuliahan Teori Bodi Otomotif di Prodi PTM JPTK FKIP UNS. JIPTEK, Vol. VI No.2, Juli 2013.

Mulyono, Budi. 2013. Pemanfaatan Media Sosial Edmodo pada Pembelajaran Matematika bagi Guru-guru SD di Kota Palembang. Prosiding Seminar Pendidikan Nasional, Mataram 8 Desember 2013.

Ratnasari, Anita. 2012. Studi Pengaruh Penerapan E-Learning Terhadap Keaktifan Mahasiswa dalam Kegiatan Belajar Mengajar Studi Kasus Universitas Mercu Buana Jakarta. Seminar Nasional Aplikasi Teknologi Informasi 2012 (SNATI 2012) ISSN: 1907-5022 Yogyakarta, 15-16 Juni 2012. 